\title{
AFROCENTRISM, GAZE AND VISUAL EXPERIENCE IN ZORA NEALE HURSTON'S THEIR EYES WERE WATCHING GOD
}

\author{
Afrocentrismo, mirada y experiencia visual en Their Eyes Were Watching God de \\ Zora Neale Hurston
}

\section{Norman Marín Calderón*}

\author{
So Ah ast, 'where is me? Ah don't see me'. \\ Hurston, Their Eyes Were Watching God 9.
}

\begin{abstract}
This essay focuses on how, in Zora Neale Hurston's novel Their Eyes Were Watching God (1937), African American women get noticed through the use of gaze and visual experience. The marginalization African American women have experienced over the years makes them produce an alternative communication system based on sight and visual understanding. That is, the visual takes over the impossibility of black women to express themselves verbally: instead of voice there is sight.
\end{abstract}

Key Words: Afrocentrism, women, gaze, visibility, visual experience, communication.

\section{RESUMEN}

Este ensayo se concentra en cómo, en Their Eyes Were Watching God (1937) de Zora Neale Hurston, las mujeres afroamericanas se hacen notar a partir del uso de la mirada y experiencias de índole visual. La marginalización que las mujeres afroamericanas han experimentado a lo largo del tiempo hace que produzcan un sistema de comunicación alternativo basado en la vista y la comprensión visual. Es decir, lo visual se antepone a la imposibilidad que tienen las mujeres negras para expresarse verbalmente: en vez de lo verbal está lo visual.

Palabras claves: Afrocentrismo, mujeres, mirada, visibilidad, experiencia visual, comunicación.

\footnotetext{
${ }^{*}$ Universidad de Costa Rica. Profesor de la Escuelas de Lenguas Modernas y Filología, Lingüística y Literatura. Costa Rica. Correo electrónico: normanmarin@ @otmail.com

Recepción: 21-04-2017 Aceptación: 24-05-2017
} 
In her novel Their Eyes Were Watching God (1937), Zora Neale Hurston (1891-1960) gives relevance and visibility to African American women through the use of gaze and different types of visual experiences. Historically, black women have been repressed and marginalized; however, in order to give voice to her female characters, Hurston constructs an alternative communication system based on the production of gaze and diverse subjective visual experiences. For instance, the author concentrates on singular visual encounters the protagonist employs to respond to and subvert patriarchal oppression. This visual response is Afrocentric and womanist in nature.

Womanism is a neologism coined by African American writer Alice Walker which refers to the act of black women breaking silence and oppression, that is, to gain a self-defined voice to speak up their own womanhood and female desire. Moreover, womanism is a concept used as a standpoint to "talk back" against patriarchal normative discourses and impositions. That being said, this paper employs the terms "womanist", "black", "African American", "Africana" and "Afrocentric" interchangeably in the sense that black female experience is completely different from the hegemonic whiteness; or as Molefi Kete Asante points out, "one who does not know white American culture can [not] truly understand it without some background, neither can Afrocentric writers be understood without some background" (1992, p. 16). In fact, Their Eyes Were Watching God can be better comprehended only if it is considered from an African American-womanist-standpoint. In her famous Africana Womanist, Clenora Hudson-Weems purposely affirms that:

Africana people have long been denied not only the authority of naming self, but of defining self. It is now of utmost importance that we take control over both those determining interconnected factors in our lives if we hope to avoid degradation, isolation, and annihilation in a world of [white] greed, violence, and pandemonium. (HudsonWeems, 2004, p. 18)

Consequently, as an African American woman in a white male dominated society, Zora Neale Hurston creates a fictional character-Janie — who is initially oppressed, and whose voice has no authority to be heard and considered. But it is precisely due to this muteness and invisibility that the author can build upon an alternative way of communication - the visual, which eventually serves to later convey her ideas and desires. 
In fact, Their Eyes Were Watching God is an Afrocentric novel written by an African American female author who "immerses herself...in the culture of the [black] people. The value of this immersion is that one becomes more authentically a voice of the [African American] culture" (Asante, 1992, p. 17). Or as Alice L. Nicholas also puts it: "in African American ("Negro") communication, it is not the idea itself that makes the technique unique, but the way in which African American ("Negro") expresses that idea that sets the African American ("Negro") art of communication apart" (2013, p. 26). This means that Africana literary theory and criticism offer a proper Afrocentric perspective of analysis and inquiry because examining a text using another culture means to impose another value system which may be counterproductive and even dangerous. Thus, one way African American women can express their own culture and desire is by the gaze and visual interaction.

Through gaze, African American women may construct their own identity and in doing so, give voice to their own desires. It is as Nanny_Janie's grandmother_says: “...but we don’t know nothin' but what we see" (Hurston, 2004, p. 14). Indeed, critic Deborah Clarke asserts that "by recognizing visual difference, Hurston suggests that is crucial to understand how [Africana] identity is constructed: by skin and color" (2001, p. 599). Thus Janie can express herself as a black woman in so far she has the ability to look: “...in a sense, Janie's talking is looking” (Burrows, 2001, p. 435). That is to say, the only way to gain visibility and understanding both as a woman and as an African American individual is by the use of subjective visual experiences, even so that Their Eyes promulgates the significance and repercussion of the visual in its very title.

Through its own title, Hurston's novel evidences a visual text. It exhorts that even in the most defiant of situations, the capability to see promotes the ability to recognize self and communicate with others. This is clearly exemplified in the scene of the hurricane where Janie, Tea Cake and Motor Boat "huddled closer and stare[d] at the door...they didn't look at anything but the door... Six eyes [were] questioning God" (emphasis added, Hurston, 2006, p. 159). This scene reveals that words are both meaningless and insufficient for communication; only watching is essential as "They sat in company with the others in other shanties, their eyes straining against crude walls and their souls asking if He [God] meant to measure their puny might against His. They seemed to be staring at the dark, but their eyes were watching God" (emphasis added, Hurston, 2006, p. 160). This passage manifests that gaze is the only proven 
approach to connect with the Source and ascertain truth. Whereas the characters (learn to) watch, their true selves communicate with God to the extent that their eyes were directly watching Him.

Janie, the protagonist of Their Eyes, decides not to talk but instead she uses gaze and the visual as a more proper mode of communicating and declaring her desire. She takes the visual as a subjective experience of self-liberation, that is, as a "...source of strength and a kind of language, thus redeeming visibility and establishing voice" (Clarke, 2001, p. 601). Clarke continues elaborating that:

Hurston's Janie makes readers "see" her story... She thus manages to present a material self that can withstand the power of the gaze, transforming it into a source of strength. In establishing a rhetoric of sight, Hurston ensures that black bodies remain powerfully visible throughout the novel, particularly the bodies of black women. (2001, p. 600)

Indeed, the power of gaze and the opportunity for visibility are the keystone of womanist identity and subjectivity. Or as bell hooks explains it: “...all attempts to repress our/black people's right to gaze produced in us an overwhelming longing to look, a rebellious desire, and oppositional gaze. With it, not only will I stare. I want my look to change reality" (Hooks, 1992, p. 116). Thus, in transforming female gaze into a tool to scrutinize Africana practices and desire, looking becomes a pivotal experience for black women. At this respect, Michelle Wallace elucidates that "how one is seen (as black) and, therefore, what one sees (in a white world) is always already crucial to one's existence as an Afro-American. The very markers that reveal you to the rest of the world, your dark skin and your kinky/curly hair, are visual" (1990, p. 40). Of course, this type of vision more than being literal also has to be understood in a figurative, even paradoxical context.

In Their Eyes Were Watching God, Nanny-Janie's grandmother-represents a freer African American tradition she wants to instill in her granddaughter. Nanny embodies these types of Africana values in so far as she herself has endured white dominance and patriarchal oppression so that she has learned to communicate in ways other than the hegemonic social norm. And this is exactly what she transmits to Janie. Or as Sherley Anne Williams affirms, Nanny has "...suffered most of the abuses heaped upon African American women-hard physical labor, poor rations, whippings, the threat of being separated from children and mate, coerced sexual relations with master and vindictive treatment at the hands of the mistress" (Williams, 2000, p. 22). Therefore, Nanny wishes to transfer this type of wisdom and visual 
communication system to Janie. Although owned and abused, Nanny teaches her granddaughter to desire since “...nothing can’t stop you from wishin'. You can’t beat nobody down so low till you can rob 'em of they will" (Hurston, 2006, p. 16).

Indeed, this new kind of womanist communication scheme is mainly visual, where gaze and sight are fundamental modes of naming and defining self. Since black women have historically been silenced by (white hegemonic) patriarchy, they have learned to convey their desire differently from the spoken word. On the opposite, speech might make them get into trouble, or as Mary Hellen Washington points out: "speech does not lead Janie to power...but to self-division and to further acquiescence in her status as object" (1977, p. 30). Thus, instead of talking, black women "watch" and express themselves through their eyes.

It is through gaze and sight that African American women have gained visibility. For instance, when she turns seventeen, Leafy-Janie's mother-is raped by her schoolteacher, so Janie is conceived out of that violent act. That is why Nanny is so protective of her granddaughter. In the scene when Janie sees Johnnie Taylor "tall and lean. That was before the golden dust of pollen had beglamored his rags and her eyes" (Hurston, 2006, p. 12), Nanny knows he may take advantage of her granddaughter so she, instead of talking to Janie, would rather look at her because a glance tells more than a thousand words. Nanny's eyes “didn't bore and pierce. They diffused and melted Janie, the room and the world into one comprehension" (Hurston, 2006, p. 12). In fact, when Nannie realizes Janie has understood what her gaze meant, her grandmother "closed her eyes and nodded a slow, weary affirmation many times before she gave it a voice... Yeah, Janie, Ah wants to see you married right away... [but not with] a trashy nigger, ... like Johnny Taylor usin' yo' body to wipe his foots on” (Hurston, 2006, p. 12-13).

Nonetheless, Janie cannot yet comprehend her grandmother's gaze, so Nanny does insist: “Look at me, Janie. Don't set dere wid yo' head hung down. Look at yo' ole grandma!" (emphasis added, Hurston, 2006, p. 13). Still, Janie is reluctant to obey Nanny and that is when "she slapped the girl's face violently, and forced her head back so that their eyes met in struggle" (p. 14). As it can be discerned, words are not sufficient to convey the message, so Nanny needs sight to teach her granddaughter a lesson. Indeed, "the highly ambivalent presentation of voice in Their Eyes indicates that voice alone is not enough" (Clarke, 2001, p. 599). Or as the narrator of the novel herself states: "There is a basin in the mind where words float around on thought and 
thought on sound and sight. Then there is a depth of thought untouched by words, and deeper still a gulf of formless feelings untouched by thought" (Hurston, 2006, p. 24).

On the same token, love is one of the topics Hurston's novel explores through gaze and visual communication, especially as exemplified by the relationship between Janie and Tea Cake. In this sense, loves begins with a glance, or as Janie herself notes, life is “...all according to the way you see things. Some people could look at a mud puddle and see an ocean with ships" (Hurston, p. 89). And this is what happens with love as well. In fact, Janie's love for Tea Cake started with sight since "he looked like the love thoughts of women. He could be a bee to a blossom - a pear tree blossom in the spring... He was a glance from God" (emphasis added, Hurston, 2006, p. 106).

Janie's relationship with Tea Cake begins with a loving look as she tells him: "Look lak Ah seen you somewhere... Ah'm easy tuh see on Church Street most any day or night" (Hurston, 2006, p. 94-95). Here the controlling gaze of patriarchy is debased yet transformed into a vision of understanding and acceptance. When they are playing the checker game, Tea Cake invites her to "watch" all the possible moves in the game, to be attentive, that is, to have her eyes opened. He tells her: "You ain't supposed tuh look off, Mis' Starks. It's de biggest part uh de game tuh watch out! Leave go mah hand" (Hurston, 2006, p. 96). According to Deborah Clarke, Tea Cake's response accentuates the importance of female gaze, “...of using one's vision not to fix and specularize but to see and think, to understand" (Clarke, 2001, p. 607). At this moment of visual revelation, the protagonist realizes there is an-other who can validate her own (female) gaze so that she allows herself to characterize her lover employing a visual metaphor: "he was a glance from God" (p. 106).

Gaze not only initiates, but also finishes, the love relationship with Tea Cake: Love begins with sight and ends with it as well. When Tea Cakes contracts rabies Janie perceives his pain in horror: "Janie saw a changing look come in his face. Tea Cake was gone. Something else was looking out of his face" (emphasis added, Hurston, 2006, p. 181). And Tea Cake watches in return: "He gave her a look full of blank ferocity and gurgled in his throat. She saw him sitting up in bed and moving about so that he could watch her every move" (emphasis added, p. 182). Here there are two individuals watching each other watch, "and a third - the reader-[who] participates fully" (Tangum and Smelstor, 1988, p. 92). At this moment of intense vision, Tea Cake_-ill and delusional — tries to kill Janie, so she defends herself shooting at him: She "saw 
the ferocious look in his eyes... Janie saw the look on his face... She saw him stiffen himself all over as he leveled and took aim" (emphasis added, Hurston, 2006, p. 184).

In sum, gaze and visual communication are pivotal elements of analysis in Hurston's novel since they play a crucial role in the formation of Janie's subjectivity. The medium employed by the author to render account of this identity process is photography as it works as the vehicle for self-recognition and self-understanding: It is because of some photographs that Janie is able to recognize her own blackness. By telling her best friend Pheoby that "unless you see de fur, a mink skin ain't no different from a coon hide" (Hurston, 2006, p. 7), the protagonist is equating seeing with knowing, which means that individuals can truly understand themselves only when they are able to "see." She did not know she was a black woman until she saw herself in some pictures:

Ah was wid dem white chillum so much till Ah didn't know Ah wuzn't white till Ah was round six years old. Wouldn't have found it out then, but a man come long takin' pictures and without askin' anybody... So when we looked at de picture and everybody got pointed out there wasn't nobody left except a real dark little girl with long hair standing by Eleanor. Dat's where Ah wuz s'posed to be, but Ah couldn't recognize dat dark chile as me. So Ah ast, 'where is me? Ah don't see me'...Dat's you, Alphabet, don't you know yo' ownself? Dey all useter call me Alphabet 'cause so many people had done named me different names. Ah looked at de picture a long time and seen it was mah dress and mah hair so Ah said: Aw, aw! Ah'm colored! Den dey all laughed real hard. But before Ah seen de picture Ah thought Ah wuz just like the rest. (Emphasis added, Hurston, 2006, p. 8-9)

Janie's distress at the revelation of her own blackness reveals that she did not know who she was until the picture uncovers her identity: she knows about herself mainly because she was able to see her own image in the photograph. Or as Roland Barthes asserts: "you are the only one who can never see yourself except as an image: you never see your eyes unless they are dulled by the gaze that rests upon the mirror or the lens..." (Barthes, 1981, p. 36). Nonetheless, in order to vindicate her own self and identity, Janie must restitute the image in the photograph with herself.

The photographs thus expose Janie the color of her skin which reveals she occupies a separate place from the (white hegemonic) others. Before seeing the pictures, she has never 
differentiated herself from the others: “... before Ah seen de picture Ah thought Ah wuz just like the rest” (p. 9). In fact, to apprehend one's race means to realize one's place, a place marked by otherness. Samira Kawash notes at this respect that:

The visible marks of the racialized body are only the signs of a deeper, interior difference, and yet those visible marks are the only difference that can be observed. The body is the sign of a difference that exceeds the body. The modern concept of race is therefore predicated on an epistemology of visibility, but the visible becomes an insufficient guarantee of knowledge. (Kawash, 1997, p. 130)

In short, the visual territory is the place where racial, thus subjective, identity is constructed; nevertheless, it is precisely due to the recognition requited by these photos that Janie can initiate a journey of self-discovery and a process of realization - a process where she - an object of the other's gaze - can become a free and authentic individual. This reversal of object into subject is possible due to the significance of gaze where the woman can now recognize who she really is to the extent that she assertively turns to the mirror in a moment of self-recognition: "She went over to the dresser and looked hard at her skin and features. The young girl was gone, but a handsome woman had taken her place. She tore off the kerchief from her head and let down her plentiful hair" (Hurston, 2006, p. 87).

In predicating a rhetoric of sight, with her novel, Zora Neale Hurston confirms that African American women remain compellingly visible and actual. In fact, Their Eyes Were Watching God ends with a visionary scene that sums up the womanist thesis which confirms that African American identity and subjectivity is constructed through the power of gaze as, by the end of the novel, Janie "...pulled in her horizon like a great fish-net. Pulled it from around the waist of the world and draped it over her shoulder. So much of life in its meshes! She called in her soul to come and see" (emphasis added, Hurston, 2006, p. 193). Therefore, the novel concludes with such a scene that does highlight the capability of black women to see, which here represents freedom and self-recognition. For Hurston, gaze and vision communication serve as a genuine means for African American women to express themselves, as a Deborah Clarke assertively notes: "her accomplishment is nothing less than redefining African American rhetoric, rendering it verbal and visual"' (emphasis added, Clarke, 2001, p. 611). 


\section{Bibliography}

Asante, Molefi Kete. (1992). "Locating a Text: Implications of Afrocentric Theory.” Language and Literature in the African American Imagination. Ed. Carol Aisha Blackshire-Belay. Westport: Greenwood Press, 9-20.

Barthes, Roland. (1981). Roland Barthes by Roland Barthes. Trans. Richard Howard. New York: Hill and Wang.

Burrows, Stuart. (2001). "You Heard Her, You Ain't Blind: Seeing What's Said in Their Eyes Were Watching God." In: NOVEL: A Forum on Fiction, 34 (3), 434-452.

Clarke, Deborah. (2001). “The Porch Couldn't Talk for Looking: Voice and Vision in Their Eyes Were Watching God." African American Review, 35 (4), 599-613.

Hudson-Weems, Clenora. (2004). Africana Womanist Literary Theory. Trenton: Africana World Press.

Hurston, Zora Neale. (2006). Their Eyes Were Watching God. New York: Harper Perennial.

Hooks, Bell. (1992). Black Looks: Race and Representation. Boston: South End Press.

Kawash, Samira. (1997). Dislocating the Color Line: Identity, Hybridity and Singularity in African-American Narrative. Stanford: Stanford University Press.

Nicholas, Alice L. (2013). The Non-Verbal Visual as Agency: African American Women's Communication in Zora Neale Hurston's Their Eyes Were Watching God. MA Thesis. California State University at Dominguez Hill.

Tangum, Marion M., and Marjorie Smelstor. (1988). “Huston's and Angelou's Visual Art: The Distancing Vision and the Beckoning Gaze.” The Southern Literary Journal, 31 (1), 80-97. Wallace, Michelle. (1990). "Modernism, Postmodernism and the Problem of the Visual in AfroAmerican Culture." In: Out There: Marginalization and Contemporary Cultures. Ed. Russell Ferguson et al. Cambridge: MIT Press, 39-50.

Washington, Mary Hellen. (1977). "Teaching Black-Eyed Susans: An Approach to the Study of Black Women Writers.” Black American Literature Forum, 11 (1), 20-25.

Williams, Sherley Anne. (2000). "Encountering Zora Neale Hurston." In: Their Eyes Were Watching God: A Casebook. Ed. Cheryl Wall. Oxford: Oxford University Press, 59-116. 